\title{
TOTAL ADIPONECTIN LEVELS IN DYSLIPIDEMIC INDIVIDUALS: RELATIONSHIP TO METABOLIC PARAMETERS AND INTIMA-MEDIA THICKNESS
}

\author{
David Karasek $^{\text {a*}}$, Helena Vaverkova ${ }^{a}$, Milan Halenka ${ }^{a}$, Dagmar Jackuliakova ${ }^{a}$, \\ Zdenek Frysak ${ }^{\mathrm{a}}$, Dalibor Novotny ${ }^{\mathrm{b}}$
}

\author{
a $3^{\text {rd }}$ Department of Internal Medicine, University Hospital Olomouc, Czech Republic \\ ${ }^{b}$ Department of Biochemistry, University Hospital Olomouc \\ E-mail: david.karasek@fnol.cz
}

Received: July 13, 2010; Accepted with revision: August 31, 2010

Key words: Adiponectin/Dyslipidemia/Insulin resistance/Intima-media thickness

Introduction. Adiponectin is adipocytokin with anti-inflammatory and anti-atherogenic effects. However, studies examining the relationship between adiponectin and cardiovascular diseases have shown inconsistent results.

Aims. The aim of this study was to evaluate the plasma levels of adiponectin in clinically asymptomatic subjects with various dyslipidemic phenotypes. The associations between adiponectin and risk factors for atherosclerosis, markers of insulin resistance, and the intima-media thickness of the common carotid artery (IMT) were also evaluated.

Methods. 234 asymptomatic subjects were divided into four dyslipidemic phenotypes (DLP) according to apolipoprotein $\mathrm{B}(\mathrm{apoB})$ and triglycerides (TG): DLP1 ( $\mathrm{n}=58$, apoB $<1.2 \mathrm{~g} / 1$ and $\mathrm{TG}<1.5 \mathrm{mmol} / \mathrm{l})$, DLP2 $(\mathrm{n}=47$, apoB $<1.2$ $\mathrm{g} / 1$ and TG $\geq 1.5 \mathrm{mmol} / \mathrm{l}), \mathrm{DLP} 3(\mathrm{n}=31, \mathrm{apoB} \geq 1.2 \mathrm{~g} / 1$ and $\mathrm{TG}<1.5 \mathrm{mmol} / \mathrm{l})$ and DLP4 $(\mathrm{n}=98$, apoB $\geq 1.2 \mathrm{~g} / 1$ and TG $\geq 1.5$ $\mathrm{mmol} / 1$ ). DLP1 (normo-apoB/normo-TG) served as a control group.

Results. Significant differences in adiponectin levels between normolipidemic phenotype - DLP1 (16.1[10.3-20.8] $\mathrm{mg} / \mathrm{l})$ and hypertriglyceridemic phenotypes - DLP2 (9.5[6.8-13.0] mg/l, p<0.01) and DLP4 (10.1[7.4-16.8] mg/l, $\mathrm{p}<0.01)$ after adjustment for age, sex and body mass index were found. Adiponectin correlated positively with highdensity lipoprotein cholesterol and apolipoprotein A1 (apoA1), negatively with triglycerides, apoB/apoA1, highsensitivity C-reactive protein, insulin, homeostasis model assessment and waist circumference. ApoA1 and insulin were detected as independent predictors for adiponectin levels in multivariate regression analysis. Adiponectin did not correlate with IMT.

Conclusions. Individuals with hypertriglyceridemic phenotypes showed decreased adiponectin levels in comparison with normolipidemic subjects. Adiponectin was associated with lipid parameters, markers of insulin resistance, chronic inflammation and visceral obesity. But no association between adiponectin and IMT was found.

\section{INTRODUCTION}

Adiponectin is an adipocytokin produced mostly by mature adipocytes ${ }^{1,2}$. In the three main forms adiponectin is present in plasma: trimer (low molecular weight), hexamer (middle molecular weight) and even multimeric complex (high molecular weight, HMW) (ref., ${ }^{3,4}$ ). Although some studies have proposed that the ratio of the HMW to other forms may serve as a better indicator of metabolic disorders, the majority of studies that have linked adiponectin to metabolic diseases have used assays for total adiponectin ${ }^{5}$. Adiponectin has an insulin-sensitizing effect on hepatocytes - leading to hepatic glucose output suppression ${ }^{6}$ and on muscles - by stimulating fattyacid oxidation ${ }^{7}$. Adiponectin also has anti-inflammatory properties. By inhibiting tumor necrosis factor-alpha it reduces the expression of cell adhesion molecules in the endothelium ${ }^{8}$ and has many other anti-atherogenic effects. Adiponectin accumulates in the arterial wall of injured arteries ${ }^{9}$, suppresses lipid accumulation and inhibits mac- rophages to foam-cell transformation ${ }^{10}$ and smooth muscle cell proliferation ${ }^{11}$.

Low levels of adiponectin were found in subjects with obesity $^{12,13}$, type 2 diabetes mellitus ${ }^{13,14}$, hypertension ${ }^{15,16}$ and dyslipidemia ${ }^{5,17-19}$. Initially, low levels of adiponectin were also found in patients with coronary artery disease independently of other risk factors ${ }^{20,21}$. However, studies examining the relationship between adiponectin and cardiovascular diseases in humans have had inconsistent results $^{22-24}$. Findings from a meta-analysis suggest that the magnitude of the association between adiponectin levels and cardiovascular disease may not be as strong as has been previously considered ${ }^{25}$.

The aim of this study was to evaluate the plasma levels of adiponectin in clinically asymptomatic dyslipidemic subjects and investigate the relationship between adiponectin and the intima-media thickness of the common carotid artery (IMT) an acknowledged morphological marker of early atherosclerosis and predictor of future cardiovascular events ${ }^{26}$. We also studied whether selected risk factors for atherosclerosis and markers of insulin resistance are related to adiponectin levels. 


\section{MATERIALS AND METHODS}

\section{Study design and subjects}

The study was carried out on subjects who had been examined at the Lipid Center of the $3^{\text {rd }}$ Department of Internal Medicine, University Hospital Olomouc, Czech Republic in period October 2007 to October 2009. All subjects filled out a questionnaire on their medical history, especially cardiovascular status, medication and smoking habits. Body mass index (BMI), waist circumference, systolic and diastolic blood pressure (SBP, DBP) were determined. All subjects were tested for an underlying cause of secondary hyperlipidemia: diabetes mellitus, hypothyroidism, hepatic or renal impairment and nephrotic syndrome. Subjects with these diagnoses were not enrolled in the study. Other exclusion criteria were as follows: history of clinically manifest atherosclerosis (coronary artery disease, cerebrovascular ischemic disease and peripheral arterial disease), hypolipidemic treatment in the previous 8 weeks, hormone therapy with estrogens and clinical presence of acute infectious disease or trauma. The study was reviewed and approved by institutional Ethics Committee of the Medical Faculty and University Hospital Olomouc and informed consent was obtained from all participants. Individuals who met the above criteria $(n=234)$, were divided into four dyslipidemic phenotypes (DLP) according to Sniderman classification based on apolipoprotein B and triglycerides ${ }^{27}$ : DLP $1(\mathrm{n}=58$, apoB $<1.2 \mathrm{~g} / 1$ and $\mathrm{TG}<1.5 \mathrm{mmol} / 1)$, DLP $2(\mathrm{n}=47$, apoB $<1.2 \mathrm{~g} / 1$ and $\mathrm{TG} \geq 1.5 \mathrm{mmol} / 1)$, DLP 3 $(\mathrm{n}=31, a p o B \geq 1.2 \mathrm{~g} / 1$ and $\mathrm{TG}<1.5 \mathrm{mmol} / \mathrm{l})$, DLP $4(\mathrm{n}=98$, apoB $\geq 1.2 \mathrm{~g} / 1$ and $\mathrm{TG} \geq 1.5 \mathrm{mmol} / \mathrm{l})$. A value $1.5 \mathrm{mmol} / \mathrm{l}$ for TG was chosen in this classification, because it is at this level that small dense LDL particles become common. A value $1.2 \mathrm{~g} / 1$ for apoB was chosen, because at this level the cardiovascular risk rapidly increased. This value corresponds to the $75^{\text {th }}$ percentile of the North American population, the level chosen to define an elevated LDL-C $\left(\right.$ ref. $\left.{ }^{27}\right)$. Subjects with DLP 1 - who were normolipidemic (normo-apoB / normo-TG mmol/l) - served as a control group.

\section{Biochemical analyses}

Venous blood samples were drawn in the morning after a 12-hour fast. Total cholesterol, triglycerides and HDLcholesterol were determined enzymatically on Modular SWA analyzer (Roche, Basel, Switzerland) using commercially available kits (Cholesterol SYS 917, Triglycerides GPO-PAP and HDL cholesterol plus, $3^{\text {rd }}$ generation kits, Roche, Basel, Switzerland). Determination of HDL-C was made by a direct method without precipitation of apo B containing lipoproteins. LDL-C levels were calculated according to the Friedewald formula (for TG $<4.5 \mathrm{mmol} / \mathrm{l}$ ). We also calculated non-HDL cholesterol (non-HDL-C $=$ TC - HDL-C). Concentration of apoB and apolipoprotein A1 (apoA1) was determined immunoturbidimetrically on Modular SWA analyzer (TinaQuant Apo A1, TinaQuant Apo B kits, all Roche, Basel, Switzerland). High-sensitivity C-reactive protein (hs-CRP) was assessed by means of an ultra sensitive latex immunoturbidimetric method on
Modular SWA analyzer (CRP latex TinaQuant kit, all Roche, Basel, Switzerland). Glycemia was determined by enzymatic-colorimetric method (Glucose GOD-PAP kit) on Modular SWA analyzer (all Roche, Basel, Switzerland). Insulin was determined using the commercially available kits - Insuline (Immunotech, Marseille, France) using specific antibodies by IRMA (immunoradiometric assay) method. The result obtained was then used for calculation of the parameter of insulin resistance HOMA [homeostasis model assessment, described by Matthews et al. ${ }^{28}$. fasting glycemia $(\mathrm{mmol} / \mathrm{l})$, fasting insulin $(\mathrm{mU} / \mathrm{l}) / 22.5]$. $\mathrm{C}$-peptide and intact proinsulin were determined using the commercially available kits - C-peptide (Immunotech, Marseille, France) and Proinsulin (DRG Instruments $\mathrm{GmbH}$, Marburg, Germany) using specific antibodies by IRMA method (for C-peptide) and RIA method (for proinsulin). Adiponectin was determined in the serum by ELISA (Biovendor Laboratory Medicine Inc., Brno, Czech Republic) according to manufacturer's instructions. Both, the intra- and inter-assay coefficient of variation were below $10 \%$. Concentrations of adiponectin, insulin, proinsulin, C-peptide and hs-CRP were measured in the serum stored at $-80^{\circ} \mathrm{C}$.

\section{IMT measurement}

Ultrasound scanning of IMT was performed with a 10 MHz linear array transducer (Philips Sonos 5500, 2004). All measurements were performed with the subjects in a supine position. The head was tilted to the one side at an angle of $45^{\circ}$. The longitudinal B-mode image of the common carotid artery (CCA) was displayed just before the widening of the bulb. When an optimal longitudinal image of the far wall of the CCA in the region of $1 \mathrm{~cm}$ proximally from the bulb was obtained, it was frozen on the $\mathrm{R}$ wave according to a simultaneous ECG and videotaped. Three video records were made on both CCA. IMT measurements were processed off-line using the software Image-Pro Plus (Version 4.0, Media-Cybernetics, Silver Spring, USA). The region under evaluation was the CCA wall $1-2 \mathrm{~cm}$ distant proximally from the mentioned border. The average of all mean IMT of three frozen images of both sides was chosen as the outcome variable. The measurement of IMT was made without knowledge of laboratory results.

\section{Statistical analyses}

All values are expressed as means $\pm \mathrm{SD}$ or as median with 25 and 75 percentiles for variables with non-normal distribution. The Kolmogorov-Smirnov test was used to test for normal distribution. Variables with non-normal distribution (TG, proinsulin, insulin, C-peptide, HOMA, hs-CRP, adiponectin) were log transformed to normalize their distribution before statistical analysis. Differences in means between groups were analyzed using ANOVA after adjustment for age, sex and BMI. For statistical evaluation of correlations between parameters we used a univariate Pearson correlation analysis. Multivariate regression analysis was used for testing for an independent association between dependent and independent variables. Statistical analysis was performed using SPSS for Windows ver- 
sion 12.0 (Chicago, Illinois, USA). Probability values of $\mathrm{p}<0.05$ were considered as statistically significant.

\section{RESULTS}

\section{Basic characteristics and adiponectin levels}

Table 1 shows the biochemical, anthropometric characteristics, IMT and adiponectin levels in individual DLPs. Individuals with hyper-apoB DLPs (DLP 3 and 4) had significantly increased total cholesterol and LDL-C, individuals with hyper-TG DLPs (DLP 2 and 4) had decreased HDL-C and apoA1 compared to normolipidemic subjects (DLP 1). Non-HDL-C and apoB/apoA1 significantly rose from DLP 1 to DLP 4 . Subjects with hyper-TG DLPs (DLP 2 and 4) showed increased markers of insulin resistance (HOMA, C-peptide, insulin, proinsulin), obesity (BMI, waist circumference) and inflammation (hsCRP) compared to DLP 1. In all dyslipidemic patients (DLP 2, 3 and 4) higher blood pressures (SBP, DBP) were measured. The highest elevation of IMT was observed in patients with simultaneously elevated levels of TG and of apoB (DLP 4). Significant differences were found in levels of adiponectin between DLP 1 and hypertriglyceridemic phenotypes (DLP 2 and 4), adiponectin levels did not differ between DLP 1 and DLP 3 - see also Fig. 1.

Relation of adiponectin to selected metabolic parameters, anthropometric parameters and IMT

Levels of adiponectin correlated positively with HDL-C $(r=0.39, p<0.001)$ and apoA1 $(r=0.34, p<0.001)$, negatively with TG $(\mathrm{r}=-0.32, \mathrm{p}<0.001)$, apoB/apoA1 $(\mathrm{r}=$ 0.33 , $\mathrm{p}<0.001)$, hs-CRP $(\mathrm{r}=-0.16, \mathrm{p}<0.05)$, insulin $(\mathrm{r}=-0.24$, $\mathrm{p}<0.01)$, HOMA $(\mathrm{r}=-0.22, \mathrm{p}<0.01)$ and waist circumference $(\mathrm{r}=-0.34, \mathrm{p}<0.001)$. Adiponectin din not correlate with IMT for individual DLPs, nor for all subjects.

IMT correlated with age $(\mathrm{r}=0.35, \mathrm{p}<0.001)$, TC $(\mathrm{r}=0.47, \mathrm{p}<0.001)$, apoB $(\mathrm{r}=0.33, \mathrm{p}<0.001), \mathrm{TG}(\mathrm{r}=0.35$, $\mathrm{p}<0.001)$, non-HDL-C $(\mathrm{r}=0.39, \mathrm{p}<0.001)$, proinsulin $(\mathrm{r}=0.24, \mathrm{p}<0.01)$, C-peptide $(\mathrm{r}=0.21, \mathrm{p}<0.01)$, BMI $(\mathrm{r}=0.28, \mathrm{p}<0.001)$, waist $(\mathrm{r}=0.39, \mathrm{p}<0.001), \mathrm{SBP}(\mathrm{r}=0.39$, $\mathrm{p}<0.001)$ and DBP $(\mathrm{r}=0.24, \mathrm{p}<0.01)$.

Using a multiple regression analysis (adiponectin as dependent variable and correlated parameters - TG, HDL-C, apoA1, apoA1/apoB, hs-CRP, insulin, HOMA, waist circumference as independent predictors), in all subjects adiponectin was independently predicted by apoA 1 (beta $=0.403, p<0.01$ ), insulin (beta $=0.448, p<0.001)$ and HOMA (beta $=-0.160, p<0.01$ ). When this test with the same variables was used only in hypertriglyceridemic subjects (DLP $2+4$ ), levels of adiponectin were predicted by apoA1 (beta $=0.468, p<0.01$ ) and insulin (beta $=0.363$, $\mathrm{p}<0.05)$.

\section{DISCUSSION}

The results show significantly lower levels of adiponectin in clinically asymptomatic hypertriglyceridemic subjects (DLP 2 and 4) after adjustment for age, sex and body mass index than normolipidemic individuals (DLP 1). Adiponectin levels did not differ between individuals with separately increased levels of apoB (DLP 3 ) and subjects with DLP 1 . Levels of adiponectin correlated positively with HDL-C and apoA1, negatively with TG, apoB/apoA1, hs-CRP, insulin, HOMA and waist circumference. Independent predictors for adiponectin were detected apoA1, insulin and HOMA

Decreased levels of adiponectin in women with dyslipidemia were found for the first time by Matsubara el al. ${ }^{17}$. In this study, adiponectin levels also positively correlated with HDL-C or apoA1 levels and negatively with TG, atherogenic index (TC - HDL-C/HDL-C), apoB and apoE. A large number of studies have confirmed a positive correlation between plasma adiponectin and HDL-C, or apo A1 and an inverse relationship with TG (ref. ${ }^{5,12-}$ ${ }^{14,17-19,29-31}$ ). The mechanism linking plasma adiponectin and apoA 1 has not been fully clarified. Matsuura et al. ${ }^{32}$ showed adiponectin increasing HDL assembly caused by apoA1 synthesis in the liver through enhancing the ATP-binding cassette transporter (ABCA 1) pathway. The same author's group described adiponectin up-regulated the expression of ABCA1 in human macrophages and increased cholesterol efflux to apoA1 $\left(\right.$ ref. $\left.{ }^{33}\right)$. Moreover, a strong negative correlation between adiponectin and apoA1 catabolism independent of obesity, insulin resistance and the content of TG within HDL particle was found by Verges et al. ${ }^{34}$. These authors suggested that adiponectin could be an important link between insulin resistance and increased apoA1 catabolism.

The insulin resistance was also acknowledged as an independent predictor for adiponectin. The close negative relationship between insulin resistance and adiponectin was found in type 2 diabetes ${ }^{5,13,14}$ and in insulin-resistant state $^{5,13,35,36}$. Although epidemiological and experimental studies have found an association between insulin resistance and low plasma adiponectin levels, it has not been established whether decreased adiponectin levels are the cause or the effect of this dysregulated metabolic state. Development of hyperinsulinemia may be one possible mechanism for the suppression of adiponectin levels seen in these states. Some studies found acute suppressive effects of insulin on adiponectin ${ }^{37,38}$. However, hyperinsulinemia per se seems unlikely to be a mediator of low adiponectin levels since levels of adiponectin remained low in the later stages of type 2 diabetes in association with decreased circulating insulin levels ${ }^{39}$. Moreover, a few studies of insulin treatment have indicated no significant change in blood levels of adiponectin with chronic insulin administration ${ }^{40,41}$. Adipocyte insulin action or signal transduction rather than absolute levels of insulin may regulate adiponectin secretion. Bogan and Lodish showed that secretion of adiponectin by adipocytes requires phosphatidylinositol 3-kinase (PI-3K), a major intermediate of insulin signaling activity ${ }^{42}$. Insulin-stimulated insulin receptor substrate 1 (IRS-1)-associated with PI-3K activity was found to be reduced in adipocytes of type 2 diabetic subjects ${ }^{43}$. Thus lower adipocyte PI-3K activity may contribute to the decreased adiponectin levels. 
Table 1. Basic characteristics in dyslipidemic phenotypes.

\begin{tabular}{|c|c|c|c|c|}
\hline & DLP 1 & DLP 2 & DLP 3 & DLP 4 \\
\hline $\mathrm{n} / \mathrm{men}$ & $58 / 16$ & $47 / 27$ & $31 / 11$ & $98 / 45$ \\
\hline $\begin{array}{l}\text { Age } \\
\text { (years) }\end{array}$ & $42.0 \pm 10.4$ & $47.3 \pm 10.2$ & $47.5 \pm 12.3$ & $50.8 \pm 10.9$ \\
\hline $\begin{array}{l}\mathrm{TCH} \\
(\mathrm{mmol} / \mathrm{l})\end{array}$ & $5.18 \pm 1.01^{\mathrm{b}, \mathrm{c}, \mathrm{d}}$ & $5.76 \pm 0.90^{\mathrm{a}, \mathrm{c}, \mathrm{d}}$ & $7.31 \pm 1.12^{\mathrm{a}, \mathrm{b}}$ & $7.40 \pm 1.18^{\mathrm{a}, \mathrm{b}}$ \\
\hline $\begin{array}{l}\text { TG }{ }^{9} \\
(\mathrm{mmol} / \mathrm{l})\end{array}$ & $0.98[0.76-1.22]^{\mathrm{b}, \mathrm{d}}$ & $2.28[1.45-4.66]^{\mathrm{a}, \mathrm{c}}$ & $1.21[0.95-1.43]^{\mathrm{b}, \mathrm{d}}$ & $2.44[1.9-3.45]^{\mathrm{a}, \mathrm{c}}$ \\
\hline $\begin{array}{l}\text { HDL-CH } \\
(\mathrm{mmol} / 1)\end{array}$ & $1.68 \pm 0.47^{\mathrm{b}, \mathrm{d}}$ & $1.27 \pm 0.35^{\mathrm{a}, \mathrm{c}}$ & $1.80 \pm 0.36^{\mathrm{b}, \mathrm{d}}$ & $1.38 \pm 0.38^{\mathrm{a}, \mathrm{c}}$ \\
\hline $\begin{array}{l}\text { LDL-CH } \\
(\mathrm{mmol} / \mathrm{l})\end{array}$ & $3.04 \pm 0.82^{\mathrm{c}, \mathrm{d}}$ & $3.26 \pm 0.70^{\mathrm{c}, \mathrm{d}}$ & $4.98 \pm 1.03^{\mathrm{a}, \mathrm{b}}$ & $4.74 \pm 1.06^{\mathrm{a}, \mathrm{b}}$ \\
\hline $\begin{array}{l}\text { non-HDL } \\
-\mathrm{CH}(\mathrm{mmol} / \mathrm{l})\end{array}$ & $3.41 \pm 0.76^{\mathrm{b}, \mathrm{cd}}$ & $4.54 \pm 1.02^{\mathrm{a}, \mathrm{c}, \mathrm{d}}$ & $5.36 \pm 1.05^{\mathrm{a}, \mathrm{b}, \mathrm{d}}$ & $6.06 \pm 1.22^{\mathrm{a}, \mathrm{b}, \mathrm{c}}$ \\
\hline $\begin{array}{l}\text { apoB } \\
(\mathrm{g} / \mathrm{l})\end{array}$ & $0.90 \pm 0.19^{\mathrm{c}, \mathrm{d}}$ & $1.03 \pm 0.13^{\mathrm{c}, \mathrm{d}}$ & $1.41 \pm 0.23^{\mathrm{a}, \mathrm{b}}$ & $1.47 \pm 0.25^{\mathrm{a}, \mathrm{b}}$ \\
\hline $\begin{array}{l}\text { apo A1 } \\
(\mathrm{g} / \mathrm{l})\end{array}$ & $1.65 \pm 0.31^{\mathrm{b}, \mathrm{d}}$ & $1.48 \pm 0.32^{\mathrm{a}, \mathrm{c}}$ & $1.67 \pm 0.24^{\mathrm{b}, \mathrm{d}}$ & $1.54 \pm 0.30^{\mathrm{a}, \mathrm{c}}$ \\
\hline apoB/apoA1 & $0.56 \pm 0.16^{\mathrm{b}, \mathrm{d} d}$ & $0.73 \pm 0.18^{\mathrm{a}, \mathrm{c}, \mathrm{d}}$ & $0.86 \pm 0.18^{\mathrm{a}, \mathrm{b}, \mathrm{d}}$ & $0.99 \pm 0.27^{\mathrm{a}, \mathrm{b}, \mathrm{c}}$ \\
\hline $\begin{array}{l}\text { HOMA }{ }^{9} \\
\left(\mathrm{mIU} \mathrm{mmol}^{*} \mathrm{l}^{2}\right)\end{array}$ & $1.3[0.8-1.8]^{\mathrm{b}, \mathrm{d}}$ & $1.8[1.1-3.0]^{\mathrm{a}, \mathrm{c}}$ & $1.1[0.8-1.6]^{\mathrm{b}, \mathrm{d}}$ & $1.7[1.2-2.5]^{\mathrm{a}, \mathrm{c}}$ \\
\hline $\begin{array}{l}\text { C-peptide }{ }^{\prime} \\
(\mathrm{mg} / \mathrm{l})\end{array}$ & $1.6[1.3-2.0]^{\mathrm{b}, \mathrm{d}}$ & $2.5[1.9-3.4]^{\mathrm{a}, \mathrm{c}}$ & $1.5[1.3-2.5]^{\mathrm{b}, \mathrm{d}}$ & $2.4[1.8-3.1]^{\mathrm{a}, \mathrm{c}}$ \\
\hline $\begin{array}{l}\text { Insulin }{ }^{9} \\
(\mathrm{mIU} / \mathrm{l})\end{array}$ & $5.9[4.0-8.3]^{\mathrm{b}, \mathrm{d}}$ & $8.8[5.3-13.2]^{\mathrm{a}, \mathrm{c}}$ & $5.5[3.4-7.7]^{\mathrm{b}, \mathrm{d}}$ & $7.5[5.6-10.5]^{\mathrm{a}, \mathrm{c}}$ \\
\hline $\begin{array}{l}\text { Proinsulin " } \\
(\mathrm{mIU} / 1)\end{array}$ & $8.8[6.8-11.2]^{\mathrm{b}, \mathrm{d}}$ & $13.8[10.5-21.7]^{\mathrm{a}, \mathrm{c}}$ & $10.7[8.5-14.4]^{\mathrm{b}, \mathrm{d}}$ & $11.7[9.7-17.4]^{a, c}$ \\
\hline $\begin{array}{l}\text { hs-CRP I } \\
(\mathrm{mg} / \mathrm{l})\end{array}$ & $1.0[0.6-2.1]^{\mathrm{b}, \mathrm{d}}$ & $1.4[0.9-4.2]^{\mathrm{a}}$ & $1.2[0.6-2.9]^{\mathrm{d}}$ & $1.8[1.0-3.1]^{\mathrm{a}, \mathrm{c}}$ \\
\hline $\begin{array}{l}\mathrm{SBP} \\
(\mathrm{mm} \mathrm{Hg})\end{array}$ & $122.2 \pm 11.6^{b, c, d}$ & $132.2 \pm 18.5^{\mathrm{a}}$ & $133.2 \pm 17.6^{\mathrm{a}}$ & $133.1 \pm 14.6^{\mathrm{a}}$ \\
\hline $\begin{array}{l}\begin{array}{l}\text { DBP } \\
(\mathrm{mm} \mathrm{Hg})\end{array} \\
\end{array}$ & $76.6 \pm 8.6^{\mathrm{b}, \mathrm{c,d}}$ & $81.9 \pm 11.2^{\mathrm{a}}$ & $81.7 \pm 7.3^{\mathrm{a}}$ & $83.7 \pm 8.6^{\mathrm{a}}$ \\
\hline $\begin{array}{l}\text { BMI } \\
\left(\mathrm{kg} / \mathrm{m}^{2}\right)\end{array}$ & $24.0 \pm 3.2^{\mathrm{b}, \mathrm{d}}$ & $27.9 \pm 3.3^{\mathrm{a}, \mathrm{c}}$ & $25.0 \pm 3.2^{\mathrm{b}}$ & $26.7 \pm 3.1^{\mathrm{a}}$ \\
\hline $\begin{array}{l}\text { Waist } \\
(\mathrm{cm})\end{array}$ & $79.09 .8^{\mathrm{b}, \mathrm{d}}$ & $92.2 \pm 12.0^{\mathrm{a}, \mathrm{c}}$ & $83.8 \pm 9.9^{\mathrm{b}, \mathrm{d}}$ & $90.7 \pm 9.3^{\mathrm{a}, \mathrm{c}}$ \\
\hline $\begin{array}{l}\text { Smoking } \\
(\%)\end{array}$ & $5^{\mathrm{d}}$ & 14 & 11 & $22^{\mathrm{a}}$ \\
\hline $\begin{array}{l}\text { IMT } \\
(\mathrm{mm})\end{array}$ & $0.62 \pm 0.10^{\mathrm{d}}$ & $0.70 \pm 0.12$ & $0.69 \pm 0.09$ & $0.73 \pm 0.12^{\mathrm{a}}$ \\
\hline $\begin{array}{l}\text { Adiponectin } \\
(\mathrm{mg} / \mathrm{l})^{9}\end{array}$ & $16.1[10.3-20.8]^{\mathrm{b}, \mathrm{d}}$ & $9.5[6.8-13.0]^{\mathrm{a}}$ & $13.7[11.0-19.4]$ & $10.1[7.4-16.8]^{a}$ \\
\hline
\end{tabular}

DLP = dyslipidemic phenotype; DLP 1: apoB $<1.2 \mathrm{~g} / 1+\mathrm{TG}<1.5 \mathrm{mmol} / 1$, DLP 2: apoB $<1.2 \mathrm{~g} / 1+\mathrm{TG} \geq 1.5 \mathrm{mmol} / 1$, DLP $3:$ apoB $\geq 1.2 \mathrm{~g} / 1+$ TG $<1.5 \mathrm{mmol} / 1, \mathrm{DLP} 4: \mathrm{apoB} \geq 1.2 \mathrm{~g} / 1+\mathrm{TG} \geq 1.5 \mathrm{mmol} / 1$

$\mathrm{TC}=$ total cholesterol, $\mathrm{TG}=$ triglycerides, HDL-C $=$ HDL cholesterol, LDL-C $=$ LDL cholesterol, non-HDL-C = non-HDL cholesterol $(\mathrm{TC}-$ HDL-C), apoB = apolipoprotein B, apoA1 = apolipoprotein A 1, HOMA = homeostasis model assessment [fasting glycemia (mmol/l) , fasting insulin $(\mathrm{mU} / \mathrm{l}) / 22.5$ ], hs-CRP $=$ high sensitivity $\mathrm{C}$ reactive protein, $\mathrm{SBP}=$ systolic blood pressure, $\mathrm{DBP}=$ diastolic blood pressure, $\mathrm{BMI}=$ body mass index, IMT = intima-media thickness

Values are expressed as mean \pm S.D., for " (parameters with skewed distribution) median [25 and 75 percentiles].

Differences in variables between subgroups were analyzed with ANOVA after adjustment for age, sex and BMI. Significant difference $p<0.05$ at least $-{ }^{\mathrm{a}}$ vs. DLP $1 ;{ }^{\mathrm{b}}$ vs. DLP 2; ${ }^{\mathrm{v}}$ vs. DLP $3 ;^{\mathrm{d}}$ vs. DLP 4.

Parameters with skewed distribution (TG, proinsulin, insulin, C-peptide, HOMA, hs-CRP) were log transformed to normalize their distribution before statistical analysis. 


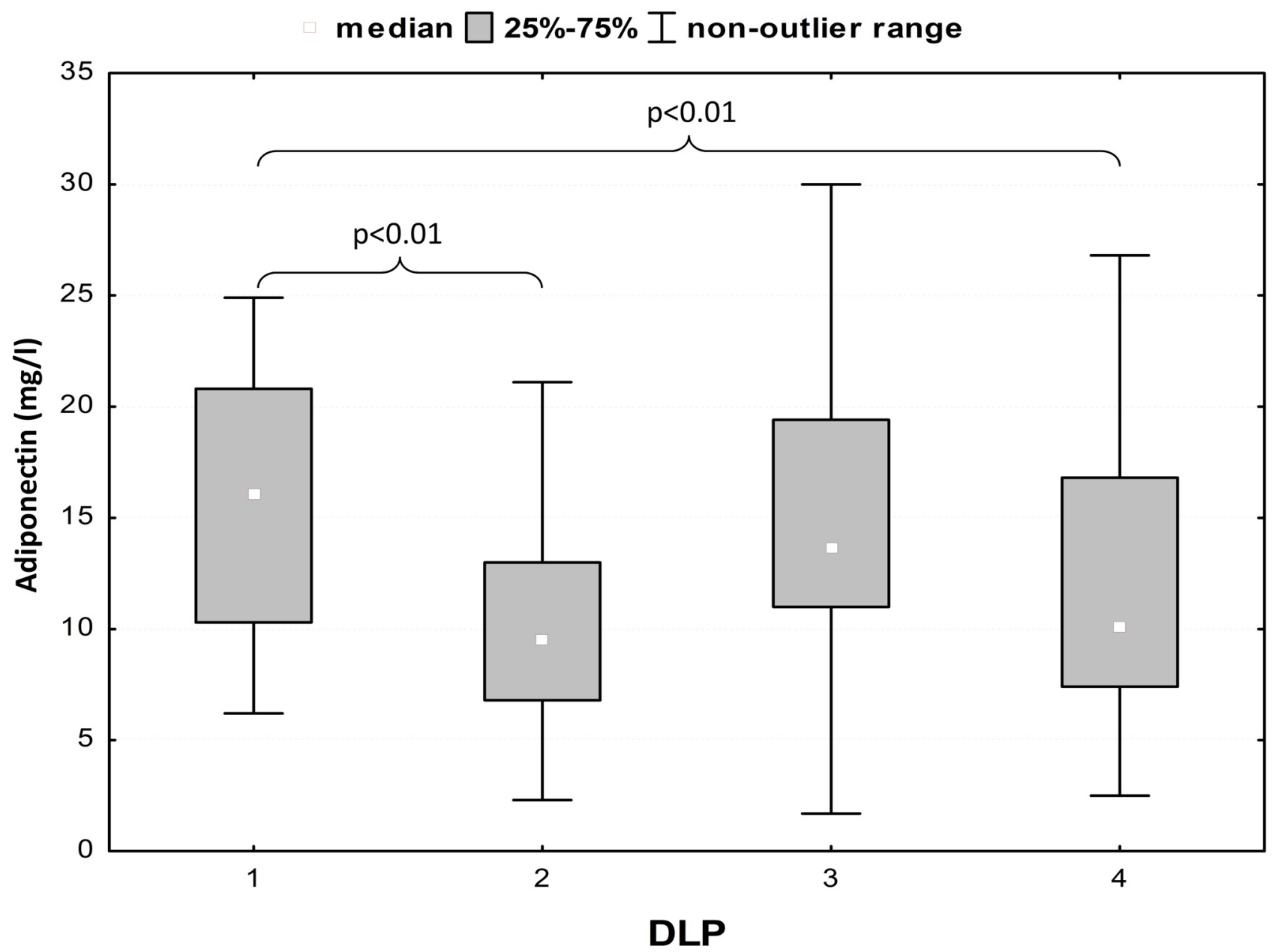

Fig. 1. Adiponectin in individual dyslipidemic phenotypes.

DLP = dyslipidemic phenotype;

DLP 1: apoB $<1.2 \mathrm{~g} / 1+\mathrm{TG}<1.5 \mathrm{mmol} / 1$, DLP 2: apoB $<1.2 \mathrm{~g} / 1+\mathrm{TG} \geq 1.5 \mathrm{mmol} / 1$,

DLP 3: $\operatorname{apoB} \geq 1.2 \mathrm{~g} / 1+\mathrm{TG}<1.5 \mathrm{mmol} / 1, \quad$ DLP $4: \mathrm{apoB} \geq 1.2 \mathrm{~g} / 1+\mathrm{TG} \geq 1.5 \mathrm{mmol} / 1$

Surprisingly, we found no association between serum adiponectin levels and subclinical atherosclerosis. Adiponectin did not correlate with IMT for any of the DLPs, or in all subjects of the present study. The significant increase in IMT was observed only in patients with hyper-apoB / hyper-TG phenotype. Publications on the relationship between these parameters are not entirely consistent. Some authors report a negative association between adiponectin and IMT (ref. ${ }^{44-49}$ ), but no relationship has been found in other studies ${ }^{19,50-54}$. Two papers pointed to a significant correlation between adiponectin and IMT in men but not in women ${ }^{55,56}$. Mangge et al. ${ }^{47}$ found the HMW subfraction of adiponectin correlated better with IMT than total adiponectin level. We did not assed adiponectin subfractions, but for instance Koenen et al. ${ }^{57}$ did not show correlation between IMT and total adiponectin, nor its multimers (including HMW adiponectin) in patients with familial combined hyperlipidemia. Recently moreover, Holewijn et al. ${ }^{53}$ found no independent association between total adiponectin levels and sev- en noninvasive measurements of atherosclerosis (NIMA) - IMT, presence of plaque, plaque thickness, pulse wave velocity, augmentation index, ankle-brachial index at rest, and ankle-brachial index after exercise. Participants with low adiponectin levels showed an increased IMT, but the association of low adiponectin level with subclinical atherosclerosis was not independent of other major cardiovascular risk factors. On the basis of absence of independent association between adiponectin level and NIMA, the authors suggested a non-causal role of adiponectin in the deterioration of NIMA. In the present study, IMT proved to correlate with age, lipid parameters, markers of insulin resistance and that of visceral obesity and blood pressure. These parameters seem to be risk factors for IMT instead of adiponectin. Low adiponectin levels in hypertriglyceridemic subjects may reflect presenting insulin resistance. However, lack of correlation between adiponectin and IMT does not argue for adiponectin as an independent predictor for next cardiovascular events in clinically asymptomatic, dyslipidemic individuals. 


\section{CONCLUSION}

Clinically asymptomatic individuals with hypertriglyceridemic phenotypes showed lower adiponectin levels than normolipidemic subjects. Adiponectin was associated with lipid parameters, markers of insulin resistance, chronic inflammation and visceral obesity. Decreased adiponectin levels were predicted by apo-A1 and insulin, independently of other lipid parameters, inflammation or visceral obesity. No association between adiponectin and IMT was found. In the place of adiponectin, IMT was associated with age, lipid parameters, markers of insulin resistance and visceral obesity and, blood pressure in these dyslipidemic individuals.

\section{ABBREVIATIONS}

ABCA, Adenosine-5'-triphosphate binding cassette transporter 1; ANOVA, Analysis of variance; ApoA1, Apolipoprotein A1; ApoB, Apolipoprotein B; ApoE, Apolipoprotein E; BMI, Body mass index; CCA, Common carotid artery; DBP, Diastolic blood pressure; DLP, Dyslipidemic phenotype; ELISA, Enzyme-linked immunosorbent assay; HDL, High density lipoprotein; HDL-C, HDL cholesterol; HMW adiponectin, High molecular weight adiponectin; HOMA, Homeostasis model assessment; Hs-CRP, High sensitivity $\mathrm{C}$ reactive protein; IMT, Intima-media thickness; IRMA, Immunoradiometric assay; IRS-1, Insulin-stimulated insulin receptor substrate 1; LDL, Low density lipoprotein; LDL-C, LDL-cholesterol; NIMA, Noninvasive measurement of atherosclerosis; Non-HDL-C, Non-HDL cholesterol; PI-3K, Phosphatidylinositol 3-kinase; RIA, Radioimmune assay; SBP, Systolic blood pressure; SPSS, Statistical package for the social sciences; TC, Total cholesterol; TG, Triglycerides; VLDL, Very low density lipoprotein.

\section{ACKNOWLEDGEMENT}

This work was supported by grant IGA MZCR NS/10284-3.

\section{REFERENCES}

1. Scherer PE, Williams S, Fogliano M, Baldini G, Lodish HF. A novel serum protein similar to $\mathrm{C} 1 \mathrm{q}$, produced exclusively in adipocytes. J Biol Chem 1995;270:26746-9.

2. Maeda K, Okubo K, Shimomura I, Funahashi T, Matsuzawa Y, Matsubara K. cDNA cloning and expression of a novel specific collagen-like factor, apM1 (AdiPose Most abundant Gene transcript 1). Biochem Biophys Res Commun 1996;221:286-9.

3. Pajvani UB, Du X, Combs TP, Berg AH, Rajala MW, Schulthess T, Engel J, Brownlee M, Scherer PE. Structure-function studies of the adipocyte-secreted hormone Acrp30/adiponectin. Implications fpr metabolic regulation and bioactivity. J Biol Chem 2003;278:907385 .

4. Magkos F, Sidossis LS. Recent advances in the measurement of adiponectin isoform distribution. Curr Opin Clin Nutr Metab Care 2007; 10:571-5.
5. Chang LC, Huang KC, Wu YW, Kao HL, Chen CL, Lai LP, Hwang JJ, Yang WS. The clinical implications of blood adiponectin in cardiometabolic disorders. J Formos Med Assoc 2009;108:353-66.

6. Berg AH, Combs TP, Scherer PE. ACRP30/adiponectin: an adiponectin regulating glucose and lipid metabolism. Trends Endocrinol Metab 2002;13:84-9.

7. Yamauchi T, Kamon J, Minokoshi Y, Ito Y, Waki H, Uchida S, Yamashita S, Noda M, Kita S, Ueki K, Eto K, Akanuma Y, Froguel P, Foufelle F, Ferre P, Carling D, Kimura S, Nagai R, Kahn BB, Kadowaki T. Adiponectin stimulates glucose utilization and fattyacid oxidation by activating AMP-activated protein kinase. Nat Med 2002;8:1288-95.

8. Ouchi N, Kihara S, Arita Y, Maeda K, Kuriyama H, Okamoto Y, Hotta K, Nishida M, Takahashi M, Nakamura T, Yamashita S, Funahashi T, Matsuzawa Y. Novel modulator for endothelial adhesion molecules: adipocyte-derived plasma protein adiponectin. Circulation 1999;100:2473-6.

9. Okamoto Y, Arita Y, Nishida M, Muraguchi M, Ouchi N, Takahashi M, Igura T, Inui Y, Kihara S, Nakamura T, Yamashita S, Miyagawa J, Funahashi T, Matsuzawa Y. An adipocyte-derived plasma protein, adiponectin, adheres to injured vascular walls. Horm Metab Res 2000;32:47-50.

10. Ouchi N, Kihara S, Arita Y, Nishida M, Matsuyama A, Okamoto Y, Ishigami M, Kuriyama H, Kishida K, Nishizawa H, Hotta K, Muraguchi M, Ohmoto Y, Yamashita S, Funahashi T, Matsuzawa Y. Adipocyte-derived plasma protein, adiponectin, suppresses lipid accumulation and class A scavenger receptor expression in human monocyte-derived macrophages. Circulation 2001;103:1057-63.

11. Arita Y, Kihara S, Ouchi N, Maeda K, Kuriyama H, Okamoto Y, Kumada M, Hotta K, Nishida M, Takahashi M, Nakamura T, Shimomura I, Muraguchi M, Ohmoto Y, Funahashi T, Matsuzawa Y. Adipocyte-derived plasma protein adiponectin acts as a platelet-derived growth factor-BB-binding protein and regulates growth factor-induced common postreceptor signal in vascular smooth muscle cell. Circulation 2002;105:2893-8.

12. Arita Y, Kihara S, Ouchi N, Takahashi M, Maeda K, Miyagawa J, Hotta K, Shimomura I, Nakamura T, Miyaoka K, Kuriyama H, Nishida M, Yamashita S, Okubo K, Matsubara K, Muraguchi M, Ohmoto Y, Funahashi T, Matsuzawa Y. Paradoxical decrease of an adipose-specific protein, adiponectin, in obesity. Biochem Biophys Res Commun 1999;257:79-83.

13. Weyer C, Funahashi T, Tanaka S, Hotta K, Matsuzawa Y, Pratley RE, Tataranni PA. Hypoadiponectinemia in obesity and type 2 diabetes: Close association with insulin resistance and hyperinsulinemia. J Clin Endocrinol Metab 2001;86:1930-5.

14. Hotta K, Funahashi T, Arita Y, Takahashi M, Matsuda M, Okamoto Y, Iwahashi H, Kuriyama H, Ouchi N, Maeda K, Nishida M, Kihara S, Sakai N, Nakajima T, Hasegawa K, Muraguchi M, Ohmoto Y, Nakamura T, Yamashita S, Hanafusa T, Matsuzawa Y. Plasma concentrations of a novel, adipose-specific protein, adiponectin, in type 2 diabetic patients. Arterioscler Thromb Vasc Biol 2000;20:1595-9.

15. Kazumi T, Kawaguchi A, Sakai K, Hirano T, Yoshino G. Young men with high-normal blood pressure have lower serum adiponectin, smaller LDL size, and higher elevated heart rate than those with optimal blood pressure. Diabetes Care 2002;25:971-6.

16. Adamczak M, Wiecek A, Funahashi T, Chudek J, Kokot F, Matsuzawa Y. Decreased plasma adiponectin concentration in patients with essential hypertension. Am J Hypertens 2003;16:72-5.

17. Matsubara M, Maruoka S, Katayose S. Decreased plasma adiponectin concentrations in women with dyslipidemia. J Clin Endocrinol Metab 2002;87:2764-9.

18. Kantartzis K, Rittig K, Balletshofer B, Machann J, Schick F, Porubska K, Fritsche A, Häring HU, Stefan N. The relationships of plasma adiponectin with a favorable lipid profile, decreased inflammation, and less ectopic fat accumulation depend on adiposity. Clin Chem 2006;52:1934-42.

19. Karásek D, Vaverková H, Halenka M, Jackuliaková D, Fryšák Z, Novotný D. Adiponectin in members of families with familial combined hyperlipidemia. Endocrinologist 2010;20:117-21. 
20. Pischon T, Girman CJ, Hotamisligil GS, Rifai N, Hu FB, Rimm EB. Plasma adiponectin levels and risk of myocardial infarction in men. JAMA 2004;291:1730-7.

21. Frystyk J, Berne C, Berglund L, Jensevik K, Flyvbjerg A, Zethelius B. Serum adiponectin is a predictor of coronary heart disease: a population-based 10-year follow-up study in elderly men. J Clin Endocrinol Metab 2007;92:571-6.

22. Laughlin GA, Barrett-Connor E, May S, Langenberg C. Association of adiponectin with coronary heart disease and mortality: the Rancho Bernardo study. Am J Epidemiol 2007;165:164-74.

23. Lawlor DA, Davey Smith G, Ebrahim S, Thompson C, Sattar N. Plasma adiponectin levels are associated with insulin resistance, but do not predict future risk of coronary heart disease in women. J Clin Endocrinol Metab 2005;90:5677-83.

24. Poehls J, Wassel CL, Harris TB, Havel PJ, Swarbrick MM, Cummings SR, Newman AB, Satterfield S, Kanaya AM; Health ABC Study. Association of adiponectin with mortality in older adults: the Health, Aging, and Body Composition Study. Diabetologia 2009;52:591-5.

25. Sattar N, Wannamethee G, Sarwar N, Tchernova J, Cherry L, Wallace AM, Danesh J, Whincup PH. Adiponectin and coronary heart disease: a prospective study and meta-analysis. Circulation 2006;114:623-9. Erratum in: Circulation 2007;115:e325.

26. Lorenz MW, Markus HS, Bots ML, Rosvall M, Sitzer M. Prediction of clinical cardiovascular events with carotid intimamedia thickness: a systematic review and meta-analysis. Circulation 2007;115:459-67.

27. Sniderman AD. Applying apoB to the diagnosis and therapy of the atherogenic dyslipoproteinemias: a clinical diagnostic algorythm. Curr Opin Lipidol 2004;15:433-8.

28. Matthews DR, Hosker JP, Rudenski AS, Naylor BA, Treacher DF, Turner RC. Homeostasis model assessment: insulin resistance and beta-cell function from fasting plasma glucose and insulin concentrations in man. Diabetologia 1985;28:412-9.

29. Huang KC, Lue BH, Yen RF, Shen CG, Ho SR, Tai TY, Yang WS Plasma adiponectin levels and metabolic factors in nondiabetic adolescents. Obes Res 2004;12:119-24.

30. Kazumi T, Kawaguchi A, Hirano T, Yoshino G. Serum adiponectin is associated with high-density lipoprotein cholesterol, triglycerides, and low-density lipoprotein particle size in young healthy men. Metabolism 2004;53:589-93.

31. Vaverkova H, Karasek D, Novotny D, Jackuliakova D, Halenka M, Lukes J, Frohlich J. Positive association of adiponectin with soluble vascular cell adhesion molecule sVCAM-1 levels in patients with vascular disease or dyslipidemia. Atherosclerosis 2008;197:725-31.

32. Matsuura F, Oku H, Koseki M, Sandoval JC, Yuasa-Kawase M, Tsubakio-Yamamoto K, Masuda D, Maeda N, Ohama T, Ishigami M, Nishida M, Hirano K, Kihara S, Hori M, Shimomura I, Yamashita S. Adiponectin accelerates reverse cholesterol transport by increasing high density lipoprotein assembly in the liver. Biochem Biophys Res Commun 2007;358:1091-5.

33. Tsubakio-Yamamoto K, Matsuura F, Koseki M, Oku H, Sandoval JC, Inagaki M, Nakatani K, Nakaoka H, Kawase R, Yuasa-Kawase M, Masuda D, Ohama T, Maeda N, Nakagawa-Toyama Y, Ishigami M, Nishida M, Kihara S, Shimomura I, Yamashita S. Adiponectin prevents atherosclerosis by increasing cholesterol efflux from macrophages. Biochem Biophys Res Commun 2008;375:390-4.

34. Vergès B, Petit JM, Duvillard L, Dautin G, Florentin E, Galland F, Gambert P. Adiponectin is an important determinant of apoA-I catabolism. Arterioscler Thromb Vasc Biol 2006;26:1364-9.

35. Bacha F, Saad R, Gungor N, Arslanian SA. Adiponectin in youth: relationship to visceral adiposity, insulin sensitivity, and beta-cell function. Diabetes Care 2004;27:547-52.

36. Hivert MF, Sullivan LM, Fox CS, Nathan DM, D'Agostino RB Sr, Wilson PW, Meigs JB.. Associations of adiponectin, resistin, and tumor necrosis factor-alpha with insulin resistance. J Clin Endocrinol Metab 2008;93:3165-72.

37. Möhlig M, Wegewitz U, Osterhoff M, Isken F, Ristow M, Pfeiffer AF, Spranger J. Insulin decreases human adiponectin plasma levels. Horm Metab Res 2002;34:655-8.
38. Dullaart RP, Riemens SC, Meinardi JR, Wolffenbuttel BH, Sluiter WJ. Plasma adiponectin is modestly decreased during 24-hour insulin infusion but not after inhibition of lipolysis by Acipimox. Scand J Clin Lab Invest 2005;65:523-31.

39. Chandran M, Phillips SA, Ciaraldi T, Henry RR. Adiponectin: more than just another fat cell hormone? Diabetes Care 2003;26:244250.

40. Miyashita Y, Nishimura R, Nemoto M, Matsudaira T, Kurata H, Yokota T, Yokota K, Tojo K, Utsunomiya K, Tajima N. Prospective randomized study for optimal insulin therapy in type 2 diabetic patients with secondary failure. Cardiovasc Diabetol 2008;7:16.

41. Juurinen L, Tiikkainen M, Häkkinen AM, Hakkarainen A, YkiJärvinen H. Effects of insulin therapy on liver fat content and hepatic insulin sensitivity in patients with type 2 diabetes. Am J Physiol Endocrinol Metab 2007;292:E829-35.

42. Bogan JS, Lodish HF. Two compartments for insulin-stimulated exocytosis in 3T3-L1 adipocytes defined by endogenous ACRP30 and GLUT4. J Cell Biol 1999;146:609-20.

43. Smith U, Axelsen M, Carvalho E, Eliasson B, Jansson PA, Wesslau C. Insulin signaling and action in fat cells: associations with insulin resistance and type 2 diabAdiponectin did not correlate with IMT for individual DLPs, nor for all subjects. etes. Ann N Y Acad Sci 1999;892:119-26.

44. Lo J, Dolan SE, Kanter JR, Hemphill LC, Connelly JM, Lees RS, Grinspoon SK. Effects of obesity, body composition, and adiponectin on carotid intima-media thickness in healthy women. J Clin Endocrinol Metab 2006;91:1677-82.

45. Kiris I, Tekin I, Yesildag A, Vural H, Oyar O, Sirin B, Okutan $\mathrm{H}$, Ibrisim E. Inverse relationship between adiponectin levels and subclinical carotid atherosclerosis in patients undergoing coronary artery bypass grafting. Int Heart J 2006;47:855-66.

46. Shargorodsky M, Boaz M, Goldberg Y, Matas Z, Gavish D, Fux A, Wolfson N. Adiponectin and vascular properties in obese patients: is it a novel biomarker of early atherosclerosis? Int J Obes (Lond) 2009;33:553-8.

47. Mangge H, Almer G, Haj-Yahya S, Pilz S, Gasser R, Möller R, Horejsi R. Preatherosclerosis and adiponectin subfractions in obese adolescents. Obesity (Silver Spring) 2008;16:2578-84.

48. Pilz S, Horejsi R, Möller R, Almer G, Scharnagl H, Stojakovic T, Dimitrova R, Weihrauch G, Borkenstein M, Maerz W, Schauenstein $\mathrm{K}$, Mangge H. Early atherosclerosis in obese juveniles is associated with low serum levels of adiponectin. J Clin Endocrinol Metab 2005;90:4792-6.

49. Iglseder B, Mackevics V, Stadlmayer A, Tasch G, Ladurner G, Paulweber B. Plasma adiponectin levels and sonographic phenotypes of subclinical carotid artery atherosclerosis: data from the SAPHIR Study. Stroke 2005;36:2577-82.

50. Muscelli E, Kozáková M, Flyvbjerg A, Kyriakopoulou K, Astiarraga BD, Glintborg D, Konrad T, Favuzzi A, Petrie J; RISC investigators. The effect of menopause on carotid artery remodeling, insulin sensitivity, and plasma adiponectin in healthy women. Am J Hypertens 2009;22:364-70.

51. Norata GD, Raselli S, Grigore L, Garlaschelli K, Dozio E, Magni P, Catapano AL. Leptin:adiponectin ratio is an independent predictor of intima media thickness of the common carotid artery. Stroke 2007;38:2844-6.

52. Arnaiz P, Acevedo M, Barja S, Aglony M, Guzmán B, Cassis B, Carvajal J, Moreno M, Navarrete C, Berríos X. Adiponectin levels, cardiometabolic risk factors and markers of subclinical atherosclerosis in children. Int J Cardiol 2010;138:138-44.

53. Holewijn S, den Heijer M, van Tits LJ, Swinkels DW, Stalenhoef AF, de Graaf J. Impact of waist circumference versus adiponectin level on subclinical atherosclerosis. J Intern Med 2010;267:588-98.

54. Kozakova M, Palombo C, Paterni M, Anderwald CH, Konrad T, Colgan MP, Flyvbjerg A, Dekker J; Relationship between Insulin Sensitivity Cardiovascular risk Investigators. Body composition and common carotid artery remodeling in a healthy population. $\mathbf{J}$ Clin Endocrinol Metab 2008;93:3325-32.

55. Nilsson PM, Engström G, Hedblad B, Frystyk J, Persson MM, Berglund G, Flyvbjerg A. Plasma adiponectin levels in relation to 
carotid intima media thickness and markers of insulin resistance. Arterioscler Thromb Vasc Biol 2006;26:2758-62.

56. Nishida M, Moriyama T, Ishii K, Takashima S, Yoshizaki K, Sugita Y, Yamauchi-Takihara K. Effects of IL-6, adiponectin, CRP and metabolic syndrome on subclinical atherosclerosis. Clin Chim Acta 2007;384:99-104.
57. Koenen TB, van Tits LJ, Holewijn S, Lemmers HL, den Heijer M, Stalenhoef AF, de Graaf J. Adiponectin multimer distribution in patients with familial combined hyperlipidemia. Biochem Biophys Res Commun 2008;376:164-8. 